\title{
Private Archives in South Africa: Their Protection and Access with Particular Reference to the now Defunct Lutheran Theological Institute Library and Archives
}

\author{
FRANCIS GARABA, PH.D. \\ University of KwaZulu-Natal - Information Studies Department, Scottsville 3209, Pietermaritzburg, South Africa \\ e-mail: garaba@ukzn.ac.za / fgaraba@yahoo.com
}

Private Archives in South Africa: Their Protection and Access with Particular Reference to the now Defunct Lutheran Theological Institute Library and Archives

\section{ABSTRACT}

This treatise is a case study that provides an insight into the status of private archives in South Africa with regards to their protection and access provisions. The paper is based on the author's experiences as a manuscript librarian at the now defunct Lutheran Theological Institute (LTI) Library and Archives and research on faith-based archives which this institution was endowed with. The thesis of this paper is that records and archives legislation in South Africa as far as it applies to private archives is lethargic and not comprehensive enough to provide an enabling environment for their stewardship which is leading to loss of documentary heritage. The demise of this institution and the subsequent loss of the collection is testimony. In consequence, faith based collections (religious archives) need to be legislated like their counterparts public archives for protection and access in terms of the law.

Key words: archives legislation, South Africa, private archives, Lutheran Theological Institute, access

Archivi privati in Sud Africa: loro protezione ed accesso con particolare riferimento per la biblioteca e l'archivio defunta dell'ex Istituto Teologico Luterano

\section{SINTESI}

Il presente articolo costituisce uno studio che fornisce uno spaccato sulla condizione degli archivi privati in Sud Africa per quanto riguarda la loro protezione e le disposizioni di accesso. L'articolo si basa sulle esperienze dell'autore come bibliotecario dei manoscritti presso la biblioteca e l'archivio dell'ex Istituto Teologico Luterano e ricerca su archivi di organizzazioni religiose che questa istituzione custodiva. La tesi di questo libro è che la legislazione su documenti ed archivi in Sud Africa, per la parte che si applica agli archivi privati, sia letargica e non abbastanza completa al fine di fornire un ambiente favorevole per la loro gestione, il che sta portando alla perdita del patrimonio documentario. La scomparsa di questa istituzione e la conseguente perdita della collezione ne è testimonianza. Di conseguenza, gli archivi religiosi necessitano di una legislazione che li consideri, come le loro controparti pubbliche, archivi per la protezione e l'accesso nei termini di legge.

Parole chiave: legislazione archivistica, Sud Africa, archivi privati, Istituto Teologico Luterano, accesso

Zasebni arhivi v Južni Afriki: Zasebni arhivi v Južni Afriki - njihova zaščita in dostop s posebnim poudarkom na trenutno neobjavljeni knjižnici in arhivu Luteranskega teološkega inštituta

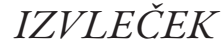

Prispevek je študija primera, ki zagotavlja vpogled v status zasebnih arhivov v Južni Afriki v zvezi z njihovimi določbami o zaščiti in dostopu. Prispevek temelji na izkušnjah avtorja kot bibliotekarja rokopisov v knjižnici in arhivu Luteranskega teološkega inštituta (LTI) in raziskavah verskih arhivov. Predpostavljena je teza, da je zakonodaja o arhivskem gradivu in arhivih v Južni Afriki, kolikor se nanaša na zasebne arhive, pomanjkljiva in ne dovolj celovita, da bi zagotovila ugodno okolje za njihovo upravljanje. To vodi v izgubo dokumentarne dediščine, čemur priča poznejša izguba zbirke kljub prizadevanju institucije. Posledično je treba zbirke bazirane na veri (verske arhive), urediti kot javne arhive $\mathrm{z}$ zaščito in dostopom v skladu z zakoni.

Ključne besede: arhivska zakonodaja, Južna Afrika, privatni arhivi, Luteranski Teološki inštitut,dostop, arhivi privatnih organizacij, poslovni arhivi, arhivi digitalnih in analognih medijev, javni mediji 
Francis GARABA: Private Archives in South Africa: Their Protection and Access with Particular Reference to the now Defunct Lutheran Theological Institute Library and Archives, 59-65

\title{
Introduction
}

The International Council on Archives (ICA 2016) noted that archives are the documentary by-product of human activity retained for their long-term value. They are contemporary records created by individuals and organisations as they go about their business and therefore provide a direct window on past events. Similarly, Gilliland (2014:3) stated that archives are a critical component of how many societies remember, are held accountable and generally conduct their affairs. Archives have always been concerned with the human record and how it can bridge time and space and remain meaningful and useful. In a nutshell, archives are a reflection and a result of what happens in society. This means that they also (re)present society's changes and dynamics (Glaudemans, Jonker and Smit 2017: ix). Archives are thus held by public and private institutions and individuals around the world and. As records with enduring value, they need to be protected and made accessible for the benefit of posterity.

Accordingly, access is the availability of records for consultation as a result both of legal authorization and the existence of finding aids (Pearce-Moses 2005). The Universal Declaration on Archives (2011) identifies one of the fundamental roles of an archivist as involving the need to make records available for use. The International Council on Archives (ICA)'s Principle of Access to Archives (2012) noted that:

\begin{abstract}
Private archives hold institutional records and personal papers that have significant value for understanding social, economic, religious, community and personal history as well as for generating ideas and supporting development. Archivists working in private institutions and managing the institution's archives should encourage their institution to provide public access to its archives, especially if the holdings will help protect rights or will benefit public interests ---.
\end{abstract}

Consequently, von Rutte (2018) noted that The Principles of Access to Archives (2012) illuminate the professional duties and competences of the archivists. In view of the importance attached to private archives as aforementioned, the need for their protection cannot be over-emphasized. Therefore such records with continuing value need to be protected and cared for. This stewardship entails risk assessment with regards to environmental conditions, natural and man-made disasters, theft, sabotage and vandalism and such safeguards will guarantee their accessibility in the near future. Apparently, protection and access have a symbiotic relationship as the overall objective is to promote use of the material. The International Council on Archives (ICA 1996) and the Archives and Records Association (ARA) code of ethics (ARA 2016) reiterated that archivists should promote the preservation and use of the world's documentary heritage. At this juncture, a look into South Africa's archival treasury will now be undertaken to contextualize this treatise.

\section{Contextual background}

South Africa has a rich archival heritage which originated as a result of an interplay of several players in the evolvement of human civilization since the arrival of the Dutch at the Cape in 1652. South Africa's documentary heritage is thus made of public, state or governmental and non-public, non-governmental or private records. The International Records Management Trust [IRMT] (1999) defined public records as those created or received and maintained in any public sector agency. In the South Africa context, public records include the records of the current national, provincial and local governments and those of past administrations including the former self-governing 'homelands' (Archival Platform 2014).

On the other hand, private records are those created, received and maintained by non-governmental organisations, families or individuals relating to their private and public affairs (IRMT 1999). Non-public records include all records that are not generated by the state. These include: the records of non-governmental organisations, political parties, liberation movements and prominent individuals who have played a role in leading the country in one way or another; the records of explorers, travellers, artists, anthropologists, ethnologists and others who have documented people, places, practices and landscape over many centuries, for different purposes; records kept by churches, missions and other institutions that contain a wealth of information for family research and social historians; evidence of past lives and memories contained in letters and other correspondence, diaries, photographs, maps, artefacts, items and clothing, etc.; recordings that give voice to indigenous languages; and the oral narratives, praise poems, customs and practices on which diverse people draw to make sense of their personal, clan and national pasts (Archival Platform 2014:19). 
Francis GARABA: Private Archives in South Africa: Their Protection and Access with Particular Reference to the now Defunct Lutheran Theological Institute Library and Archives, 59-65

In a nutshell, public and non-public records are thus evidence of the cultural diversity in South African life hence the Rainbow nation meme. Accordingly, the LTI Library had a private, in-house and academic research archive with non-public records in custody and a brief look at the collection will suffice.

\section{The collection}

The ecclesiastical library had as part of its collection a comprehensive and rich documentary heritage of print and electronic resources in the form of bulletins, books, journals, magazines etc. Kuhn (2003) recorded then that the LTI collections on the Cataloguing Network in Pietermaritzburg (CATNIP) stood at 20384 and Kuhn (2018) further confirmed that this had risen to 35752 items in the catalogue without any additions since 2015. From an archival point of view, documents relating to individual staff members, students, pastors and their papers and research, as well as to institutions, associations, curricula, conferences, student bodies, applications, welfare etc, minutes of meetings, reports, societies, committees, records of appeal and adjudication, interoffice memos, appointment books, registers, charters, constitutions and bylaws, legal papers, deeds, articles of incorporation, agreements, financial ledgers and various other papers pertaining to the different churches or missions were included in the files (Garaba and $\mathrm{Za}$ verdinos 2014a). In addition, the archival repository also maintained a historical depository of denominational journals, periodicals, convention proceedings or transactions pertaining to the Lutheran Church in South Africa. However, this rich collection is not accessible anymore with the pending dispersal of the collection as the LTI was officially closed in 2016 due to deep-seated divisions within the Lutheran Church.

The closure of the LTI and the subsequent disintegration of the collection means that these are now dark archives and the failure to protect the collection owes inter alia to the configured regulatory framework in place which is ambiguous. The Archival Platform (2014) acknowledged that while some countries have a tradition of separating the care of public and private records, in South Africa the distinction is blurred: public archives have been mandated to collect non-public records of enduring significance since the first archives legislation was promulgated in 1922 and such an arrangement does not augur well for the management of private records as the demise of the LTI shows. Apparently, there is no catalogue documentation pertaining to this archival collection on the National Archives and Records Service of South Africa (NARSSA) collection database hence the call for this review in the wake of the subsequent loss of this collection. A critical appraisal of the regulatory framework in terms of how it is impacting on protection and access to private archives will now be made with particular focus on the National Archives and Records Service of South Africa Act (NARSSSA) and the Copyright Act as this had a bearing on protection and access to private archives at the LTI.

\section{National Archives and Records Service of South Africa Act (NARSSSA), Act No. 43 of 1996 as amended}

The National Archives and Records Service of South Africa (NARSSA) is headquartered in Pretoria and with its provincial archives services constitute the national archival system and hold rich collections of public and non-public records. Its mandate primarily is to provide proper management and care of public records and the Act gives the National Archives an oversight role in relation to public records in government offices (Dominy 2017). In terms of section 13 of the Act, the National Archivist is charged with the proper management and care of public records in the custody of governmental bodies (South Africa. NARSSAA 1996). NARSSAA is thus obligated in terms of taking care of state records with little focus on the stewardship of private records and this inherent bias is not difficult to discern.

Apparently, Eberhard (2008:44) correctly pointed out that non-government archives, a category into which almost all 'small' or in-house archives fall, operate without the benefit of supporting recordkeeping legislation and the LTI scenario is a case in point. NARSSAA provides for a listing and not stewardship of such records as Section 3 (f) of the NARSSAA (1996) states that the National Archives shall maintain national registers of non-public records with enduring value and promote co-operation and co-ordination between institutions having custody of such records. This constitutes a limitation as such arrangements are contributing to the loss of such records like for instance records of faith-based collections (Garaba 2014). The framework to deal with records created by private bodies needs a rethink to avoid the LTI scenario. In the United Kingdom for instance, both public and private organizations are 
Francis GARABA: Private Archives in South Africa: Their Protection and Access with Particular Reference to the now Defunct Lutheran Theological Institute Library and Archives, 59-65

required to comply with the Data Protection Act in conformity with FOI legislation. Merely listing of private collections on the National Archives and Records Service of South Africa (NARSSA) collection database as is presently the case is cosmetic and needs to be re-examined by taking a pragmatic oriented approach in overseeing their management and protection.

This status quo is because NARSSA is hamstrung or lacks the capacity in terms of human and financial resources (Dominy 2017; See also Ngoepe 2011). Commenting on this status quo and as confirmation, the Parliamentary Monitoring Group [PMG] (2016) noted as follows:

\begin{abstract}
There were challenges in respect of budget constraints, scarce resources, outdated archival legislation, obsolete systems and equipment, poor infrastructure and insufficient academic institutions providing training.
\end{abstract}

To compound matters as alluded to by PMG (2016), the legislation is outdated and a thorough review of the 1996 Archives Act is long overdue in view of the rapid pace of technological developments in the realm of what constitutes a record vis-à-vis Freedom of Information (FOI) and privacy requirements. Issues of confidentiality and privacy are fundamental when it comes to private records (IRMT 1999). Another pointed criticism is that the NARSSAA (1996) makes general statements about access without being specific as it states: "A non-public record in the custody of the National Archives shall be available for public access subject to any conditions agreed upon at its acquisition in terms of section 14(1) of this Act" (s. 12(2). It is positive to note that the PMG (2016) confirmed that plans were afoot to correct this by noting that:

In the 2016/2017 financial year, the department will be reviewing, amending and costing the NARSSA Act.

That said, other ancillary legislative instruments will now be mentioned in passing starting with the Copyright Act as this directly impacted collections at the LTI.

\title{
Copyright Act, 1978 (as amended)
}

Copyright rules in South African copyright law exist to protect artistic works from unauthorized or inappropriate sale or use (Nicholson 2015) and in archives, this applies to both analogue or physical and electronic or digital information. Due to the lack of archival policy, the Lutheran Theological Seminary (old name before the renaming to LTI), collected denominational resources unknowingly, by accident (Garaba and Zaverdinos 2014b) and relied heavily on donor individuals which presented ownership issues. In consequence, donors could deposit and recall material at will which was quite problematic for the LTI Archives as the bulk of the material was copyrighted to the donors as it was their intellectual property. Considering that ownership and access are inextricably linked, some of the archival collection and memorabilia was repossessed by the depositors upon the demise of the LTI, as the provenance of the material is traced to them and the bulk of the collection in the archives was due to their benevolence (See Garaba and Zaverdinos 2014a). To this day, the author continues receiving emails from patrons inquiring about access to the Lutheran Archives.

\section{Protection of Personal Information Act (POPIA)}

The Protection of Personal Information Act (POPIa) was signed into law in 2013 by the then President of South Africa, Jacob Zuma. The Protection of Personal Information Act aims to:

\begin{abstract}
...promote the protection of personal information processed by public and private bodies; to introduce information protection principles so as to establish minimum requirements for the processing of personal information; to provide for the establishment of an Information Protection Regulator; to provide for the issuing of codes of conduct; to provide for the rights of persons regarding unsolicited electronic communications and automated decision making; to regulate the flow of personal information across the borders of the Republic; and to provide for matters connected therewith.
\end{abstract}

However, this POPIA is directed mainly at protecting the private information of individuals held in huge databases by banks and other institutions (Landman 2015 as cited in Dominy 2017).

Although notably promoting the protection of personal information, POPI has very negative im- 
plications for all archival organisations which collect, preserve and use personal information for historical, statistical or research purposes (SAHA 2018). Archival institutions face additional challenges specific to their role in keeping historical records. These challenges include archivist having to go through all records released to them to ensure that no unlawful personal information is contained. This exercise alone is not only time consuming but requires more financial resources to be invested in the processing of archive collections (SAHA 2018).

If archives do not have consent of the persons concerned and if that information is not already publicly available, the possible impact on the archive and the public could be that important personal information and factual history that is of public interest could be lost forever (SAHA 2018). The implications from an archival point of view are threefold (Sulej 2014:23):

i. The way archivists process records/archives will have to be changed by using a special code of conduct for processing personal information;

ii. Some amendments of policies and systems of Records Management may have to be implemented according to the rules of the Act; and

iii. Personal interviews and their transcripts from Oral History Projects containing personal information will have to be checked for consent by the interviewee before that information that can be revealed.

\section{Promotion of Access to Information Act (Act No. 2 of 2000)}

The Act was promulgated in 2000 and facilitates any resident of South Africa having access to records in any public or private institution and from an individual. The Act provisions can benefit users in accessing records but it can also be used by the authorities to deny access in order to avoid disclosure (Sulej 2014). PAIA is only applied to access records less than 20 years old. Older records should be freely accessible. However if records are poorly managed, access is compromised and in the medical field for instance, patient records have been reported to be missing.

\section{Electronic Communications and Transactions Act (ECTA), 2002}

ECTA was promulgated in 2002 and is mandated to provide for the facilitation and regulation of electronic communications and transactions in both private and public spaces leading to the development of an e-strategy for South Africa with regards to electronic service delivery. This Act legalises electronic transactions and communications in view of this globally networked society. Without reliable and authentic records or data messages, the evidential weight of electronic records will be compromised. Consequently, for electronic records to remain reliable and authentic, they have to be protected irrespective of their well-documented fragile nature for access now and in the long-term.

\section{Conclusion}

This paper highlighted the plight of private archives by focusing on the now defunct Lutheran Theological Institute Library and Archives as a case study. The archives are now dark archives as the failure to protect the collection owed largely to the ambiguous regulatory framework in place and general human negligence. The archives are not accessible anymore and are escrowed in a sub-standard storage room without the requisite specifications for a purpose-built building. The loss of this Christian heritage calls for an urgent review of records and archives legislation in South Africa to manage faith-based collections in private hands.

\section{References}

Archival Platform. (2014). State of the archives: an analysis of South Africa's national archival system. Available at: http://www.archivalplatform.org/images/resources/State_of_the_Archive_FOR_WEB.pdf(accessed on 20.01.2018).

Archives and Records Association (ARA). Code of ethics. (2016.) Available at: http://www.archives.org.uk/images/ARA_Board/ARA_Code_of_Ethics_final_2016.pdf (accessed on 20.01.2018). 
Francis GARABA: Private Archives in South Africa: Their Protection and Access with Particular Reference to the now Defunct Lutheran Theological Institute Library and Archives, 59-65

Buchmayr, F. (2004). Secularization and monastic libraries in Austria. In: Raven, J. (ed.). Lost libraries: the destruction of great book collections since antiquity, pp. 145-162. Houndmills, Basingstoke, Hampshire; New York: Palgrave Macmillan.

Dominy, G. (2017). The effects of an administrative and policy vacuum on access to archives in South Africa. Archival Science, 17 , pp. 393-408.

Eberhard, K. (2008). Getting organized. In: Betttington, J., Eberhard, K., Loo, R. and Smith, C. Keeping archives, pp. 29-60. $3^{\text {rd }}$ ed. Canberra, ACT, Australia: Australian Society of Archivists, Inc..

Garaba, F. (2014). Religious archives in the east and southern Africa regional branch of the International Council on Archives (ESARBICA) region: their importance and the need for a national framework. ESARBICA Journal, 33, pp. 46-56.

Garaba, F. and Zaverdinos, A. (2014a). The Evangelical-Lutheran Church in South Africa: an introduction to its archival resources held at the Lutheran Theological Institute (LTI) Library, and the challenges facing this archive (Part One). Missionalia: Southern African Journal of Missiology 42, (1-2), pp. 5-28.

Garaba, F. and Zaverdinos, A. (2014b). The Evangelical-Lutheran Church in South Africa: an introduction to its archival resources held at the Lutheran Theological Institute (LTI) Library, and the challenges facing this archive (Part Two). Missionalia: Southern African Journal of Missiology, 42, (1-2), pp. 29-37.

Gilliland, A. J. (2014). Conceptualizing $21^{\text {st }}$ century archives. Chicago: Society of American Archivists.

Glaudemans, A., Jonker, R. and Smit, F. (2017). Introduction. In: Glaudemans, A., Jonker, R. and Smit, F. (eds.). Archives in Liquid Times, pp.ix-xiii. 's-Gravenhage: Stichting Archiefpublicaties.

International Council on Archives [ICA]. (1996). Code of ethics. Available at: https://www.ica.org/sites/default/files/ICA_1996-09-06_code\%20of\%20ethics_EN.pdf (accessed on 20.01.2018).

International Council on Archives [ICA]. (2012). Principles of access to archives. Available at: https://www.ica. org/sites/default/files/ICA_Access-principles_EN.pdf (accessed on 20.01.2018).

International Council on Archives [ICA]. (2016). What are archives? Available: https://www.ica.org/en/what-archive (accessed on 20.01.2018).

International Records Management Trust [IRMT]. (1999). The management of public sector records: principles and context. Available at: https://www.irmt.org/documents/educ_training/public_sector_rec/IRMT_principles.pdf (accessed on 23.01.2018).

Kuhn, R. (2003). One million mark. University of Natal Library Bulletin, No. 354. Available at: http://library. ukzn.ac.za/pdfs/Pietermaritzburg\%20Library\%20Bulletin/354Jul2003.pdf (accessed on 05.01.2018).

Kuhn, R. (2018). Email letter to author on 10 January.

Ngoepe, M. (2011). Is archives and records management profession in South Africa cursed? ESARBICA Newsletter, 23, (Apr.-June), pp. 2-3.

Nicholson, D. R. (2015). The South African Copyright Law: a historical overview and challenges to address access to knowledge issues in a country in transformation. Paper presented at the $81^{\text {st }}$ IFLA World Library and Information Congress (WLIC), Cape Town, South Africa, 15-21 August.

Parliamentary Monitoring Group. (2016). Available at: https://pmg.org.za/committee-meeting/22093/ (accessed on 23.01.2018).

Pearce-Moses, R. (2005). Access. Available at: https://www2.archivists.org/glossary/terms/a/access (accessed on 23.01.2018).

South Africa. (1996). National Archives and Records Service of South Africa Act (NARSSAA). Available at: https://www.nationalarchives.gov.za/sites/default/files/National\%20Archives\%20and\%20Records\%20Service\%20Act_0.pdf (accessed on 23.01.2018).

Sulej, Z. (2014). Access to archives in South Africa in the first twenty years of democracy: is there transformation or deformation? ESARBICA Journal, 33, pp. 18-35.

Universal Declaration on Archives. (2011). Available at: https://www.ica.org/en/universal-declaration-archives (accessed on 24.01.2018).

von Rutte, H. (2018). Access to archives of organizations of faith traditions. Comma: International Journal on Archives 2016 (1-2), pp. 143-148. 
Francis GARABA: Private Archives in South Africa: Their Protection and Access with Particular Reference to the now Defunct Lutheran Theological Institute Library and Archives, 59-65

\section{SUMMARY}

Public and private records are part of South Africa's rich archival treasury which calls for uniform legislation with regards to their management to avoid selective practices as highlighted in this paper. The lethargic legislation for private archives in as far as this applies to faith based collections is once again brought into the spotlight. Faith based collections need to be legislated like their counterparts public archives so that they are available when citizens request to have access to them in terms of the law (Garaba 2014) and in so doing their protection is guaranteed. The demise of the LTI is a case study that provides lessons on the need for South Africa's documentary heritage to be protected and made available for the benefit of posterity. Archives will remain footprints of human civilization and we need them to retrace our past, promote transparency and accountability. The archival records at LTI represent an important epoch in Lutheran history and is a gap that will be difficult to fill considering the pending loss due to the dispersal. Apparently, evidence in history has shown that where such appalling mistakes are made to break-up libraries and archives as was the case with LTI, the reconstruction has often proven difficult like what happened to monastic libraries in $18^{\text {th }}$ century Austria (Buchmayr 2004:157).

Typology: 1.02 Review article

Submission date: 11.06 .2018

Acceptance date: 08.08 .2018 